\title{
Time scarcity: another health inequality?
}

\section{Lyndall Strazdins}

National Centre for Epidemiology and Population Health, The Australian National University Canberra, ACT 0200, Australia; Lyndall.Strazdins@anu.edu.au

\section{Amy L Griffin}

School of Physical, Environmental and Mathematical Sciences, University of New South Wales, Australian Defence Force Academy, Canberra, ACT 2600, Australia; e-mail: a.griffin@adfa.edu.au

\section{Dorothy H Broom, Cathy Banwell}

National Centre for Epidemiology and Population Health, The Australian National University Canberra, ACT 0200, Australia; e-mail: Dorothy.Broom@anu.edu.au, Cathy.Banwell@anu.edu.au

\section{Rosemary Korda}

Australian Centre for Economic Research on Health, The Australian National University, ACT 0200, Australia; e-mail: Rosemary.Korda@anu.edu.au

\section{Jane Dixon}

National Centre for Epidemiology and Population Health, The Australian National University Canberra, ACT 0200, Australia; e-mail: Jane.Dixon@anu.edu.au

\section{Francesco Paolucci}

Australian Centre for Economic Research on Health, The Australian National University, ACT 0200, Australia; e-mail: Francesco.Paolucci@anu.edu.au

\section{John Glover}

Public Health Information Development Unit, University of Adelaide, Adelaide, SA 5005, Australia; e-mail: John.Glover@adelaide.edu.au

Received 3 February 2010; in revised form 1 July 2010

\begin{abstract}
Considerable policy action has focused on the social patterning of health, especially the health risks associated with low income. More recent attention has turned to transport, food systems, workplaces, and location, and the way their intersections with social position and income create health inequalities. Time is another dimension that structures what people do; yet the way in which time contours health has been neglected. This paper explores (a) how time might influence health, and (b) the way in which time scarcity complicates current understandings of health inequalities. Alongside other meanings, time can be thought of as a health resource. People need time to access health services, build close relationships, exercise, work, play, care, and consume-all activities that are fundamental to health. There is evidence that the experience of time pressure is directly related to poorer mental health. Lack of time is also the main reason people give for not taking exercise or eating healthy food. Thus, another impact of time scarcity may be its prevention of activities and behaviours critical for good health. We investigate whether time scarcity, like financial pressure, is socially patterned, and thus likely to generate health inequality. The experience of time scarcity appears to be linked to variations in time devoted to employment or caring-activities closely bound to gender, status, and life course. One reason that time scarcity is socially patterned is because of the way in which caring is valued, allocated, and negotiated in households and the market. Adding paid employment to caring workloads is now normative, transforming the allocation of time within families. But caring requires a close interlocking with others' needs, which are often urgent and unpredictable, creating conflict with the linear, scheduled, and commodified approach to time required in the workplace. We review the evidence for the possibility that these time pressures are indeed contributing to socially patterned health inequalities among people caring for others. We also explore the potential for time scarcity to compound other sources of health inequality through interplays with income and space (urban form, transportation networks and place of residence). People who are both time and income poor, such as lone mothers, may face compounding barriers to good health, and the urban geography of time-scarce families represents the embedding
\end{abstract}


of time-money-space trade-offs linked to physical location. In Australia and the US, poorer families are more likely to live in mid to outer suburbs, necessitating longer commutes to work. These suburbs have inferior public transport access, and can lack goods and services essential to health such as shops selling fresh foods. We conclude with a tentative framework for considering time and health in the context of policy actions. For example, social policy efforts to increase workforce participation may be economically necessary, but could have time-related consequences that alter health. Similarly, if cities are to be made livable, health promoting, and more equitable, urban designers need to understand time and time-income-space trade-offs. Indeed, many social policies and planning and health interventions involve time dimensions which, if they remain unacknowledged, could further compound time pressures and time-related health inequality.

A vast literature attests to the association between health, income, and social position. In this paper we explore the possibility that time is another resource that is important for health. We concentrate on families with children and discuss the social patterning of time scarcity by gender and lifecourse stage, exploring the evidence on how time scarcity contributes to inequalities in health. Notions of time are closely bound to notions of income, and also to space: income, because in the labour market people invest time to earn income ('time is money'); space, because the locations of services, people, and what they do (including health-related activities) is often understood in terms of time-a one-hour drive, for example, while speed is space divided by time (May and Thrift, 2001).

An appreciation of the interplay between time, income, and space complicates current theories of health inequality. Our first proposition is that time is a resource for health and we review theory and research to examine this. The second proposition is that the demands on people's time and the experience of time scarcity is socially patterned, and hence a potential mechanism for generating health inequalities. Proposition three is that time scarcity intersects with other elements of disadvantage such as income and the geographic location of families. The spatial embedding of timeincome trade-offs could exacerbate socially patterned health risks and opportunities. Advancing this tentative theory of time in health, we aim to highlight the need for policy and intervention to address temporal and spatial dimensions to address health inequality better.

\section{Health inequality}

Health is not only shaped by biology and genetics, but by processes that originate in social structures. People's place in social hierarchies shapes their resources and exposure to health risks, as well as the extent in which they are able to engage in healthy behaviour and practices (Graham, 2004). Health inequality refers to "systematic differences in one or more aspects of health across socially, economically, demographically and geographically defined population groups or subgroups" (International Society for Equity in Health, cited by Macinko and Starfield, 2002, page 1). That is, health inequality is a result of the social patterning of health risks and resources. Not all places show the same degree of social differentiation and hierarchy; hence, health inequalities are not fixed and, consequently, reducing inequality is both a public health policy goal and a matter of social justice [see, for example, the Bangkok charter (WHO, 2005)].

Within the fields of social epidemiology and public health, emphasis has been on socioeconomic determinants of health-especially income. Income governs access to housing, nutritious food, and safe neighborhoods - all of which are established health determinants (Kawachi et al, 1999). Further, income is needed to obtain services for health (including medical care). In addition, income confers more choice and capacity 
to avert or buffer health threats: for example, by purchasing better quality food (Lynch and Kaplan, 2000). Thus, alongside its other meanings (for instance, a medium of exchange, a way of assigning value, a symbol of power and success), income can be also conceptualised as a resource needed for health. People have varying amounts of income, and they are subject to different demands on that income: income availability is also socially patterned, reflecting and generating social hierarchies and privileges that vary by gender, class, sexuality, occupation, and race. However, differences in health and mortality are observed across several axes of social differentiation, not just the economic, potentially complicating the way in which income influences health (Graham and Kelly, 2004). Ethnicity, sexuality, gender, age, location, and religion structure people's access to income as well as a range of other resources, including education, care, employment, and opportunity — and to this list we add time.

\section{Time as a health resource}

Time is socially conceived and understood: that is, what it means, how it is used, what value it takes, and who has control of it are not fixed. Time is therefore a complex concept and experience, and there are many alternative perspectives on how best to conceptualise it (see, for example Adam, 1998; 2001; Gershuny, 2000; Lakoff and Johnson, 1999). We argue that, just as income can be a valuable and finite resource for health, so too can time. In contemporary market economies a commodified understanding of time prevails, requiring new engagement from health policy and theory. Time is an input to all activities, crucial both to production and to consumption (Adam, 1998; Becker, 1965). Affluent capitalist economies are organised by the imperative of efficiency, which quantifies, exchanges, and maximises time use to increase productivity and profit (Harvey, 1989). Labour is time sold in return for a wage. This fundamental social relation between time and money, worker and employer, drives the "fascination with and structuring of societies by clock time. Clock time now 'frames' all manner of human activities" (Castree, 2009 page 39), displacing other ways of understanding time in terms of rhythms, cycles, or events (May and Thrift, 2001). Thus, saving time is equivalent to making a profit, creating a continuous and escalating motivation to frame actions and costs in terms of efficient use of time, shaping people's experience of employment and family life in temporal-financial metrics (Brown and Warner-Smith, 2005; Castree, 2009). This, then, forms the context within which health, and its social determinants, are produced, because people need time to build close relationships, exercise, work, play, care, and consume, and all are fundamental to health. If time is viewed as a finite, valuable, and measurable resource, then increasing demands on people's time (for example, urban sprawl requiring long journeys, people needing to exercise 30 minutes a day to stay healthy) will 'take' time from working, caring, leisure, sleeping, or other activities. Many of these activities also require synchronous colocation of several individuals, which constrains the flexibility of time resources.

\section{Time scarcity}

At the turn of the 20th century, efficient time use was the cornerstone of a new science of production (Taylor, 1911). Greater efficiency, coupled with mass production, lowered costs by maximising output in terms of time, making goods cheaper and more affordable. This market-based way of assigning value to time helped raise the standard of living, but it also contributed to the experience of time scarcity. Time became viewed as precious and valuable: it was to be used 'economically' - saved or spent but not wasted (Lakoff and Johnson, 1999). Little more than fifty years after Taylor's innovation, the 
economist Becker (1965, pages 513-514) observed how decisions about consumption were being based on a growing obsession with time:

"Americans are supposed to be much more wasteful of food and other goods than other persons in poorer countries, and much more conscious of time: they keep track of it continuously, make (and keep) appointments for specific minutes, rush about more, cook steaks and chops rather than time-consuming stews and so forth. They are simultaneously supposed to be wasteful - of material goods - and overly economical — of immaterial time. Yet both allegations may be correct ... the tendency to be economical about time but lavish about goods may be no paradox." These meanings attached to time generate multiple, complex, and potentially contradictory experiences of temporalities and time scarcity. The number of hours in each day cannot be increased, but people can strive to 'save' time by the way they do things, what they choose to do or not do, and the way these activities are synchronised and sequenced. Thus, people can rush through some tasks to free time for others, or attempt to combine activities as a way of saving time (Southerton, 2003). Indeed, one of the reasons why time scarcity may have become a problem is the clash between the linear way in which time is organised and commodified in market contexts and the other sorts of time. Time is divided into work time (sold to the employer) and time for the self (leisure and consumption), but time for care is another, awkward, third category of time devoted to others but not sold. Yet caring for others requires a close interlocking with their needs, the timing of which is hard to predict, schedule, and contain, especially across different locations. Schwanen (2008) describes the experience of working mothers in the Netherlands picking their children up from a childcare centre within the temporal constraint of its opening hours. Arriving before closing time was not enough, because mothers did not want their child to be left alone or be the last to be picked up. Caring therefore informed another layer of time-urgency, introducing a vital dimension missing from a quantitative understanding of time scarcity.

Practices (what people do and how) are central to the experience of time (Shove, 2009). For example, Shove argues that the experience of rushing and time pressure can be viewed as a proliferation of time-demanding social practices, not a literal lack of time itself. She uses practice-time profiles to refer to the conventions of duration, sequence, and timing associated with the accepted performance of a practice. Practices themselves evolve within a sociotemporal order, in which collective expectations and rhythms shape what is possible and acceptable. For example, car dependency and urban growth means that traversing suburbs for children's sporting activities has become normal and necessary; adding demanding temporal dimensions to parenting practices. We argue that time pressures result from the competing practices which people attempt, as some practices and activities are harder to choose, defer, or expedite than others (eg getting thirty minutes of aerobic exercise a day is easier to defer than is getting dinner on the table for the family). At the heart of our view of time scarcity lie notions of more or less discretion in the competing and contradictory experiences of market and caring time (Davies, 2001). Time discretion, caring, and employment are complicated by location and income, and all are linked to social position and privilege. This becomes particularly clear at certain points over the lifecourse, as in the case of parenting and employment.

Few children now grow up in large multigenerational families, so bringing up children is seen as the responsibility of individual parents - especially mothers (Glass, 2000). Over the past five decades family size has reduced but, paradoxically, the time and effort involved in raising children may be increasing [an additional five hours per week according to US estimates (Aguiar and Hurst, 2007)]. This time remains relatively invisible and devalued (Bianchi, 2000; Folbre, 2001): parenting is not remunerated, nor 
has a significant realignment of work-time expectations occurred despite the movement of mothers into paid work (Pocock, 2003). Indeed, global competition, increased labour flexibility, and the shift to service and knowledge economies have placed further pressures on working life (Green, 2006). Employed mothers who combine working with providing care for children therefore strive to undertake two practices which require time and are equally imperative, but are unequally socially valued (a temporal predicament). We therefore define time scarcity in a way which incorporates the embedded meanings: time scarcity is the feeling of not enough time, particularly free or discretionary time (Jabs and Devine, 2006; Robinson and Godbey, 2005). Because our definition acknowledges that some practices are less discretionary than others, it encompasses people's experience of rushing and pressure as well as the quanta of time spent on given practices.

\section{Time scarcity and health}

If time scarcity is to be believed to contribute to health inequalities, we must first demonstrate that it is consequential to health. Time pressure and perceived stress are closely related (Lundberg, 1993; Zuzanek, 2004), but investigations of health correlates yield mixed support for the contention that time scarcity impairs health. Three studies report no direct correlation between time pressure (feeling always or often rushed or pressed for time) and health problems such as cardiovascular disease (Strodl et al, 2003), stroke (Strodl and Kenardy, 2008), or general health complaints (Roelen et al, 2008). However, other studies report that time pressure correlates with poorer self-rated health, more sleep problems, and health dissatisfaction (Zuzanek, 2004), and with psychosomatic symptoms such as headaches and digestive disturbances (Höge, 2009). Long work hours are also implicated in poorer health outcomes-especially, higher rates of injury and safety breaches at work (Dembe et al, 2005), although not all studies show health impacts (eg Gray et al, 2004). The clearest evidence for a link between time scarcity and health is for mental health. Roxburgh (2006) found that time pressure predicted depression both for men and for women. Women reported more time pressure than men, and this difference explained the gender gap in depression in her US sample. Zuzanek (2004) also observed a direct correlation between time pressure and adult mental health and wellbeing in the two Canadian datasets he analysed.

The main impact on health may derive from what time scarcity prevents people doing. Lundberg (2005) argues that sufficient recovery from effort and strain protects health. Indeed the word '(re)creation' refers to leisure's restorative role. For example, significant proportions of office workers suffer from upper body musculoskeletal pain, and there are well-documented gender differences in prevalence. One reason for women's greater pain and symptoms is that their domestic work and careloads at home take time away from exercise and relaxation after work (Strazdins and Bammer, 2004). Thus the extra demands on employed women's time can contribute to their health vulnerability (see also Frankenhaeuser et al, 1989; Lundberg, 2005; Roxburgh, 2004).

Time scarcity also prevents other behaviours essential for good health. Chronic diseases are the leading killers in affluent Western nations, yet the behaviours known to prevent them (physical activity and eating healthy fresh food) require time (Roberts and Barnard, 2005). Insufficient time is the reason given most frequently for not exercising or preparing healthy food (ABS, 2006; Jabs and Devine, 2006; Jabs et al, 2007). Both sedentary and active individuals say that lack of time is their main barrier to being sufficiently active (Sherwood and Jeffery, 2000), and regular exercise is simply not feasible for many mothers (Ball et al, 2004). Similarly, most people know what constitutes a healthy diet, but nearly a quarter of EU adults say they do 
not follow good nutrition because they lack time (Lappalainen et al, 1997). Health experts have ranked time pressure and car reliance as the two most important social trends underlying the rising rates of obesity (Banwell et al, 2005).

Some people even feel they have no time to be sick, raising further questions about the way time, recovery, and health are connected. Medicines are being marketed as 'time-saving' commodities, suppressing symptoms so that people can stay on the job (Vuckovic, 1999), further fuelling the problem of 'presenteeism'-where people continue to work when they are sick (Aronsson et al, 2000). This represents a view of illness as a (time-consuming) hindrance to a productive and busy life.

Our approach extends beyond other theories of time and health such as role overload and role strain (eg Barnett and Baruch, 1985; Hecht, 2001). The theory of role overload draws attention to the number of roles people occupy. We focus on time rather than role, because the number of roles and the time they require varies by circumstance and social position (for example: the much reduced time spent with children by a father compared with a mother; or the time demands faced by an employed single mother, who occupies fewer roles than an employed married mother, who is a wife as well as an employee and a mother). Thinking about time as a health resource offers the opportunity to consider practices and activities that do not easily fit into a role framework yet are nonetheless important (travel time and exercise time are two instances). Our focus on time further allows us to consider space and income as additional, intertwined health resources in our analysis.

\section{Social patterning of time scarcity}

Health inequality means that there are unequal distributions of health determinants, and we propose that access to discretionary time is socially patterned (Graham and Kelly, 2004). In the following section we consider the linkages between employment, caring, and time. Our focus is mainly on families with children, because families are a key site of social stratification and are at the forefront of the time clash between market work and care (Spillerman, 2000; Western et al, 2007).

However, we acknowledge that the reasons for time scarcity are complex and multiple, partly linked to technology and a changed social tempo that affects everyone (Wajcman, 2008). Work hours form part of the picture. Not all people are working longer hours than in the past, and most analyses of individual work times-either men's or women's - point to a slight average decline in hours over the past fifty years (Gershuny, 2000). However, such averages ignore the intensification of work effort documented across most OECD countries (Green, 2006): people are taking fewer breaks, working faster, or multitasking, so they experience their work time as more effortful, pressured, and scarce (Aguiar and Hurst, 2007; Wacjman, 2008). Nor does a focus on individual work time capture the intersection between family life and workforce participation. Estimates of work time consider time and time expenditure as an individual property, when, as Becker's (1965) analyses underline, it is also a family resource that is negotiated and traded. Thus, although average individual work hours have declined slightly, the combined hours which households devote to paid work are rising.

In most OECD countries more than half of women with children are in the labour force, and it is by considering life course and care work that the social patterning of time scarcity is revealed (Zuzanek, 1998). For example, US data on couples with children show that in 1970, in the majority of families, fathers were the sole breadwinners. These families devoted just over 44 hours per week to paid work. But in 2000 the majority of couples with children had both parents working: these families devoted more than 80 hours a week to paid work (Jacobs and Gerson, 2001). This represents 
a major reallocation of time into paid work, but for parents the time to care remains imperative. Despite the time savings afforded by childcare and having fewer children, parents want to spend time with their children (Bianchi, 2000; Bittman, 2004; Galinsky, 1999).

If time can be considered a family resource, then an uneven, gender-based access to it is clear. For example, Australian data confirm that mothers modulate their work time according to the needs of their spouse and children, but the converse is not true. Breadwinner (sole-earner) and dual-earner fathers work identical hours regardless of the ages of their children or whether their partner works or not. Employed mothers, on the other hand, work longer hours if they have sole responsibility for earning income, compared with those mothers in dual-earner arrangements with a partner also employed (Strazdins et al, in press).

A distinct social patterning of discretionary time is the result. Men and women without children average 35 and 31 hours of leisure or free time per week, respectively, whereas fathers and mothers of infants (for whom care demands are very high) only average 8 hours and 2 hours per week, respectively (Bittman and Craig, 2005). Single, unemployed males have the most leisure time (Bittman, 1998), even though they may not experience this as an unalloyed asset (Reisch, 2001). The elderly, retired, and disabled are often thought to be relatively time-rich; however, they may face constraints on health and mobility which limit how they can use their time (Farnworth, 2003).

This uneven access to discretionary time could explain the gendered health outcomes reported by Baxter et al (2007). With the aid of data from a large representative sample of Australian parents with young children (the Growing up in Australia study, or LSAC), they compared employed mothers' and fathers' well-being across physical health (self-ratings of health, from excellent to poor) mental health (having difficulties in their life, having problems coping, psychological distress), and interpersonal wellbeing (relationship conflict and quality). They found that fathers working full time fared better than those working part time (less than 35 hours per week). This is the expected pattern, based on decades of research documenting the healthy-worker effect, whereby those with poorer health exit the workforce or work part time (Arrighi and Hertz-Picciotto, 1994; Ross and Mirowsky, 1995). Yet a reverse patterning was found for mothers who worked full time: they had worse health and well-being on all measures than mothers who worked part time. The data therefore suggests a health cost to mothers, but not fathers, from full-time work hours. We speculate that a gendered access to family-time resources and subsequent time scarcity is the cause.

Lone parents at the bottom of the family income distribution may be especially vulnerable to time scarcity and its consequent health costs (Corcoran et al, 2000). In the US, for example, welfare-to-work policies have moved lone mothers off state support, but because many are low skilled and have little bargaining power, they typically hold low-wage jobs. Their children benefit from a modest improvement in income, but the mothers are time poor, and lack the resources (including the availability of another parent or caregiver) to buffer conflicting work and home demands (Corcoran et al, 2000). A large representative study of Australian families with young children found that two thirds of full-time employed mothers in couple families report that they are always or often under time pressure, as do just under one half of full-time employed fathers (Baxter et al, 2007). These figures point to a widespread prevalence of time scarcity among couple parents, but for employed lone mothers the problem is endemic. Nearly $80 \%$ of employed lone mothers say they are often or always pressed for time (Baxter et al, 2007). 


\section{Time and income}

The difficulties faced by lone parents highlight the complexity of our analysis, because the experience and the consequences of time scarcity also depend on income and privilege. For example, professionals and managers, along with low-skilled workers and employed lone mothers, are all likely to be considered time scarce, but with very different access to income. Similarly, those who might be considered time rich could include the independently wealthy as well as people who are unemployed or underemployed. Such heterogeneity of income groupings is likely to muddy the understanding of time scarcity and health, requiring a decoupling of time and income and an interrogation of their interplay in any analysis of disadvantage.

Earlier we argued that people use time to generate income. Households can therefore respond to low income by increasing labour-force participation (Moser, 1998). Those who are well paid 'buy time' (eating out in restaurants, purchasing domestic help, and so on), but people working in very low-paid jobs are unlikely to make enough money to buy more time-saving goods and services, creating a time and income double jeopardy. Thus we would expect that different social groups are represented across time-income combinations, and this is confirmed by the classification of social disadvantage published by Merz and Rathjen (2009). They also argue that poverty and social exclusion are multidimensional and involve both time and income, creating multiple poverty regimes. In their study of 10831 German adults, they found a significant fraction of time-poor people who cannot relieve their time deficit by using money. Some $2.5 \%$ of employed adults were both income and time poor, while another $8.7 \%$ of people were time poor and had income only marginally above the poverty line. Those who were both time and income poor tended to be the most disadvantagedincluding foreigners and East Germans. People most likely to be time poor and marginal for income (poor but not below the income poverty line) were women, couple parents with more than three children, less educated, self employed, and immigrants - in other words, population subgroups often considered at risk of poorer health.

Thus, we would expect people who work in low-skilled jobs or who are prevented from increasing their work hours because of heavy unpaid demands (eg carers) to be at highest health risk, with employed lone mothers the most vulnerable. However, relatively few studies have investigated how time contributes to health in low-income families. A study by Rose (2007) is an exception. Rose illustrated how access to healthgiving resources (nutritious food) is limited by time restrictions stemming from policy solutions for low-income families. He examined the nutritional circumstances of employed lone mothers in receipt of US Food Stamps. A (related) Thrifty Food Plan supplies dietary advice and adjusts the value of Food Stamps according to recommended allowances of nutrients. The plan assumes that most meals will be prepared from unprocessed ingredients, the 'cook from scratch approach', using fresh vegetables, pulses, and whole grains, for example, which are healthier and often cheaper than processed food. The plan, however, does not take into account the time required to prepare the recommended menus, which is about 2.3 hours a day for a family of four - a time cost that does not include shopping, cleaning up, or preparation of any nonrecipe meals such as sandwiches. Virtually no other employed adult spends that much time in meal preparation. Yet US welfare reforms require recipients to be employed, so lone mothers receiving Food Stamps are faced with trading off time, money, or health. Given that they do not have the option of replacing time with money (since they lack both) it was not feasible for them to implement the plan. 


\section{Time, income, space: adding location to an analysis of health inequalities}

Time and space can be so closely intertwined that it is difficult to consider one without the other (May and Thrift, 2001). Yet, just as time (and the time-income interplay) has been neglected in most analyses of health inequalities, so too has space. Space, like time, can be viewed as a resource, fundamental for all human activities, including production. Both are finite (ie they can be used up), and they affect each other (Kellerman, 1989), because the experience of time scarcity profoundly depends on where people live (Massey, 2005). Urban spatial growth increases the requirement for more time to travel, for example. On the other hand, technologies allowing near-instant flows of information and interaction are altering the spatial relationships of activities and the experience of time (Wacjman, 2008). We have argued that one way in which time scarcity affects health is because it constrains healthy behaviour (including rest, healthy food, physical activity). Space may similarly affect health via constraints on health-related behaviours and practices, including access to health services. Therefore, we now consider the notion of space in this analysis of health and time scarcity.

Time geography theorises that human activities and relationships are mediated by time, space, and identity (ie the multiple social roles that one individual may undertake). This mediation comes in the form of one of three types of constraints: capability, coupling, or authority (Hägerstrand, 1970; 1973). 'Capability constraints' are those that are determined by needs that must be met (time for sleeping, eating, etc), but they may be facilitated or hindered by technologies, such as different modes of transportation or facilities related to procuring food (eg restaurants or supermarkets). 'Coupling constraints' are those that are derived from the need to coordinate actions between multiple individuals for joint activities (eg mothers collecting their children from childcare, discussed above). 'Authority constraints' are less tangible, but no less real: they are constraints on activities that regulate behaviours via social rules, relationships, and practices (eg workplace expectations regarding how long, and when, people should work). These constraints can lead to the re-production of spaces and timespaces for particular individuals and social groups. In other words, the collective impacts of these constraints produce social patternings of time and space that are evident at multiple spatial scales. At the individual and family scale, location shapes people's ways of living: the transport modalities they use, their household food provisioning patterns, and their leisure activities, in part through the way in which it shapes their time use (Giles-Corti and Donovan, 2002; Reidpath et al, 2002; Saelens et al, 2003). The time taken to reach a destination can be reduced by increasing the speed of travel, reducing waiting times, or by urban layouts that give access to services closer to the origin of the journey. The health consequences for the inner-city child who lives within one mile of school and walks there are different from those of a child driven to a school five miles from where they live, and both differ from the parents who drive for an hour to reach their workplaces. Thus, the location of destinations (eg houses, workplaces, schools, services, parks), and the distances between them contour people's travel choices, including the extent they might walk and cycle. Because distance embodies time, space is both a determinant of time demands and a health resource in its own right which intersects with lifecourse, work, and care.

Furthermore, just as gender, ethnic, and other identities shape access to social resources and opportunities, they also interact with location. Mothers who use their cars to fulfill the cultural demands of good mothering by 'chauffeuring' their children to activities and locations throughout the urban landscape operate within complex spatial, social, and temporal practices (Dowling, 2000). The fundamental reason for driving children across the city is not questioned and these mothers feel that their need for flexibility and time saving can only be accessed through automobile use 
(Dowling, 2000). Feminist geographers have employed time-geographic methodologies to highlight the gender-linked differences in time-space constraints (Dyck, 1990; Kwan, 1999; Kwan and Weber, 2003).

This patterning of time-space resources across different social groups offers yet another window into the potential health effects of time, and time and income tradeoffs. Many people live in outer suburbs, where housing is cheaper, because they lack sufficient income to live closer to workplaces, services, and recreation [see, for example, Osland and Thorsen's (2008) analysis of Norwegian house prices]. US and Australian cities are marked by socioeconomic cleavages in access to transport. Living in the more affordable mid to outer areas of major metropolitan centres increases car dependency, locking in a sedentary lifestyle (a health risk) with the expense of running a car and the time costs of longer commutes (Dodson and Sipe, 2007; Randolf and Holloway, 2005; Tranter, 2010). Residents of outer suburbs in Australia and the UK without cars, for example, can also face poorer access to services, including those essential to good health such as shops selling fresh foods and farmers' markets (Bromley and Thomas, 1993; Jarvis et al, 2001; Reidpath et al, 2002). Time-space accessibility of locations need not only be considered in terms of clock time. Locations may be inaccessible at certain (clock) times due to meanings attached to them. For example, mothers may risk a late-night trip to a pharmacy located in a city via public transit to get medications for their ill children, yet wait until daylight to obtain similar medications for themselves (Young, 1999).

At the scale of healthcare delivery systems, time and space constraints can have significant impacts on the health of some individuals or groups of individuals. For example, Takahashi et al (2001) demonstrated that spatial and temporal windows of access to HIV/AIDS treatment can confine ill people to particular times and places and prevent them from accessing other needed services. Some medications need to be taken at particular times, with food or away from food, some need to be refrigerated, so even adhering to a medication routine can impose time constraints on an individual's activities and where they can go (capability constraints). Additionally, Takahashi et al found that service provider practices (eg opening hours of clinics) interacted with other patterns of social relations, creating inequalities in access. The health consequences of a coalescence of low income, time scarcity, and distance from services are illustrated by the predicament of Latina women caring for children living with HIV/AIDS. These mothers, usually both time and income poor, experienced such extremely reduced spatial and temporal windows of access that they were effectively denied adequate treatment. Thus, the spatial location of time-scarce families represents the embedding of time-income trade-offs in physical location, with the potential to generate health inequalities.

\section{Time in health policy}

Our aim has been to advance a tentative theory of how time scarcity, and its interplay with income and space, contributes to health inequality. We have argued that time is a resource for health which is socially patterned, and hence a potential mechanism for generating inequalities. We also explored intersections with income and space, noting that the experience of time scarcity is closely bound up with people's income and social status, as well as where they live and work. Our analysis is incomplete, however: we have yet to include fully notions of time sovereignty or timing for example, and to put the theory to proper empirical test.

Time has become political in a new way. People feel that they are busier, more accelerated, and that their time is an increasingly scarce and valued resource (Daly, 1996). This, combined with the view that time equals money, means that people resent time costs and time wastage associated with policies or service delivery. Policy makers 
therefore ignore time at their peril. Designing interventions or service delivery procedures that take up more time is likely to be politically unpalatable as well as less likely to succeed. We now, in conclusion, offer some possible ideas for policy and practice.

First, health policy makers could consider how time relates to the intervention aims. They could focus directly on saving time for target populations, or improving the timeframes for accessing services. Timetabling to minimise wait times, or extended or synchronised opening hours of health services are two examples. Time-space considerations may mean services are colocated, and close attention is paid to their accessibility for low-income families. Moreover, time may be viewed as critical to intervention success. Time required by participants would therefore become part of cost-benefit analyses, with the aim to reduce or offset time burdens or provide time-related incentives. For example, providing childcare and meals during parenting training programmes for at-risk families has led to very high participation rates (Dumka et al, 1997). Rather than 'take time away' from other pressing priorities, one physical activity programme we have studied reframed exercise as something to be done with children or partners - in other words a way of achieving care and closeness rather than competing with them (Strazdins et al, in press).

Recent initiatives suggest there is a readiness for a new policy focus on time. In Europe and the UK, work - family integration policies are being reformulated as time policies (Anxo et al, 2007; European Foundation for the Improvement of Living and Working Conditions, 2005). The Western Australian Liveable Neighbourhoods code uses walking time as one of its metrics (Giles-Corti et al, 2007). Both the UK and Australian governments have introduced the right to request flexible work, and the federal Australian portfolio for families has recently added time to their list of vital family resources.

Time scarcity intersects in a complex manner with income, location, gender, family structure, and lifecourse, and it is fuelled by the reallocation of time to paid work in families. Although time scarcity is common among the employed and well paid, the assumption that income-poor families (including welfare recipients) are time rich could inadvertently compound their health disadvantage.

We have argued that, like income, time is a resource essential for health. One way in which low income affects health is because it prevents people buying goods and services necessary for health. Although there is evidence that time scarcity erodes health directly, the most potent health risk may be indirect, stemming from what it stops people doing. Insufficient time is the number-one barrier preventing people exercising, eating healthy food, or taking public transport. Consequently, if interventions for healthy lifestyles and sustainable living are to succeed they must understand who is at risk and evaluate the extent to which interventions impose or reduce time burdens.

Australians are spending (even) less time playing, eating, preparing food, and sleeping than they were ten years ago (ABS, 2008) and the health and social problems posed by time scarcity are unlikely to abate. For example, a major policy goal in most affluent countries is to maximise workforce participation. The intention is to support an aging population and build strong and competitive economies, crucial in the context of global financial uncertainty. But increasing workforce participation will have time-related consequences, creating further pressures on people who also care for others (elders, children, disabled). Similarly urban designers need to understand time and time-income trade-offs if cities are to be made liveable, equitable, and sustainable. Unprecedented urbanisation in developing nations makes this a global problem, especially in the megacities whose time and income poor are concentrated in outlying slums. A new politics of health and its social determinants is needed, based on a recognition that health for all is also about time. 
Acknowledgements. We thank Tessa McDonald, Helen Skeat, Nina Borojevic, and Monica Beshara for their help conducting background research, and their lively, insightful, and thoughtful views on time scarcity and health. The opinions, comments, and/or analysis expressed in this paper are those of the authors and do not necessarily represent the views of the Minister for Families, Housing, Community Services and Indigenous Affairs or the Australian Government Department of Families, Housing, Community Services and Indigenous Affairs, and cannot be taken in any way as expressions of Australian Government policy.

\section{References}

ABS, 20062004 - 05 National Health Survey: Summary of Results Catalogue No. 4364.0, Australian Bureau of Statistics, Canberra

ABS, 2008 How Australians Use Their Time Catalogue No. 4153.0, Australian Bureau of Statistics, Canberra

Adam B, 1998, "When time is money: contested rationalities of time and challenges to the theory and practice of work", WP 16, Cardiff School of Social Sciences, http://www.cardiff.ac.uk/ schoolsanddivisions/academicschools/socsi/publications/abstracts/wrkgpaper-ab16.html

Adam B, 2001, "Inception report - chapter 8: time politics in transport, online document, Foresight for Transport Project," http://www.iccr-international.org/foresight/

Aguiar M, Hurst E, 2007, "Measuring trends in leisure: the allocation of time over five decades" The Quarterly Journal of Economics 122969 - 1005

Anxo D, Fagan C, Cebrian I, Moreno G, 2007, "Patterns of labour market integration in Europe: a life course perspective on time politics" Socio-economic Review $5233-260$

Aronsson G, Gustafsson K, Dallner M, 2000, "Sick but yet at work: an empirical study of sickness presenteeism" Journal of Epidemiology and Community Health 54 502-509

Arrighi H M, Hertz-Picciotto I, 1994, "The evolving concept of the healthy worker survivor effect" Epidemiology $5189-196$

Ball K, Crawford D, Warren N, 2004, "How feasible are healthy eating and physical activity for young women?" Public Health Nutrition 7433 - 441

Banwell C, Hinde S, Dixon J, Sibthorpe B, 2005, "Reflections on expert consensus: a case study of the social trends contributing to obesity" European Journal of Public Health $15564-568$

Barnett R, Baruch G K, 1985, "Women's involvement in multiple roles and psychological distress" Journal of Personality and Social Psychology 49(1) 135 - 145

Baxter J, Gray M, Alexander M, Strazdins L, Bittman M, 2007, "Mothers and fathers with young children: paid employment, caring and wellbeing", Social Policy RP 30, Australian Government Department of Families, Community Services and Indigenous Affairs, Canberra

Becker G S, 1965, "A theory of the allocation of time" The Economic Journal 75(299) 493 - 517

Bianchi S, 2000, "Maternal employment and time with children: dramatic change or surprising continuity?" Demography $37401-414$

Bittman M, 1998, "The land of the lost long weekend? Trend in free time among working age Australians, 1974-1992”, DP 83, Social Policy Research Centre, University of New South Wales, Sydney, http://www.sprc.unsw.edu.au/media/File/dp083.pdf

Bittman M, 2004, "Parenting and employment: what time-use surveys show", in Family Time: The Social Organization of Care Eds M Bittman, N Folbre (Routledge, New York) pp 133-151

Bittman M, Craig L, 2005, "The effect of children on adults' time use: analysis of the incremental costs of children in Australia", DP 143, Social Policy Research Centre, University of New South Wales, Sydney, http://www.sprc.unsw.edu.au/media/File/DP143.pdf

Bromley R, Thomas C, 1993, "The retail revolution, the carless shopper and disadvantage" Transactions of the Institute of British Geographers, New Series 18222 -236

Brown P, Warner-Smith P, 2005, "The Taylorisation of family time: an effective strategy in the struggle to 'manage' work and life? Annals of Leisure Research 8(2/3) $75-90$

Castree N, 2009, "The spatio-temporality of capitalism" Time and Society 18 26-61

Corcoran M, Danzinger S K, Kalil A, Seefeldt K S, 2000, "How welfare reform is affecting women's work" Annual Review of Sociology 26241 - 269

Daly K J, 1996 Families and Time: Keeping Pace in a Hurried Culture (Sage, Thousand Oaks, CA)

Davies K, 2001, "Responsibility and daily life: reflections over timespace", in Timespace: Geographies of Temporality Eds J May, N Thrift (Routledge, London) pp 133-148

Dembe A, Rerikson J, Delbos R, Banks S, 2005, "The impact of overtime and long work hours on occupational injuries and illnesses: new evidence form the United States" Occupational and Environmental Medicine 62588 - 597 
Dodson J, Sipe N, 2007, "Oil vulnerability in the Australian city: assessing socioeconomic risks from higher urban fuel prices" Urban Studies $4437-62$

Dowling R, 2000, "Cultures of mothering and car use in suburban Sydney: a preliminary investigation" Geoforum $31345-353$

Dumka L E, Garza C A, Roosa M W, Stoerzinger H D, 1997, "Recruitment and retention of highrisk families into a preventive parent training intervention" The Journal of Primary Prevention $1825-39$

Dyck I, 1990, "Space, time and renegotiating motherhood: an exploration of the domestic workplace" Environment and Planning D: Society and Space $8459-483$

European Foundation for the Improvement of Living and Working Conditions, 2005, "Fourth European Working Conditions Survey", http://www.eurofound.europa.eu/pubdocs/2006/98/en/ 2/ef0698en.pdf

Farnworth L, 2003, "Time use, tempo and temporality: occupational therapy's core business or someone else's business" Australian Occupational Therapy Journal 50116 - 126

Folbre N, 2001 The Invisible Heart: Economics and Family Values (New Press, New York)

Frankenhaeuser M, Lundberg U, Fredrikson M, Melin B, Tuomisto M, Myrsten A, 1989, "Stress on and off the job as related to sex and occupational status in white-collar workers" Journal of Organizational Behaviour 10321 - 346

Galinsky E, 1999 Ask the Children (William Morrow, New York)

Gershuny J, 2000 Changing Times: Work and Leisure in Postindustrial Society (Oxford University Press, Oxford)

Giles-Corti B, Donovan R J, 2002, "The relative influence of individual, social and physical environment determinants of physical activity" Social Science and Medicine 54 1793-1812

Giles-Corti B, Knuiman M, Pikora T J, Van Neil K, Timperio A, Bull F C L, et al, 2007, "Can the impact on health of a government policy designed to create more liveable neighbourhoods be evaluated? An overview of the RESIDential Environment Project" New South Wales Public Health Bulletin 18(12) $238-242$

Glass J, 2000, "Envisioning the integration of family and work: toward a kinder, gentler, workplace" Contemporary Sociology $29129-143$

Graham H, 2004, "Social determinants and their unequal distribution: clarifying policy understandings" Milbank Quarterly 82(1) $101-124$

Graham H, Kelly M P, 2004, "Health inequalities: concepts, frameworks and policy", briefing paper, Health Development Agency, London

Gray M, Qu L, Stanton D, Weston R, 2004, "Long work hours and the wellbeing of fathers and their families" Australian Journal of Labour Economics 7255 - 273

Green F, 2006 Demanding Work: The Paradox of Job Quality in the Affluent Economy (Princeton University Press, Princeton, NJ)

Hägerstrand T, 1970, "What about people in regional science?" Papers of the Regional Science Association 247 - 21

Hägerstrand T, 1973, “The domain of human geography”, in Directions in Geography Ed. R Chorley (Methuen, London) pp $67-87$

Harvey D, 1989 The Condition of Postmodernity (Blackwell, Cambridge, MA)

Hecht L M, 2001, "Role conflict and role overload" Sociological Inquiry 71 111-121

Höge T, 2009, "When work strain transcends psychological boundaries: an inquiry into the relationship between time pressure, irritation, work - family conflict and psychosomatic complaints" Stress and Health $2541-51$

Jabs J, Devine C M, 2006, "Time scarcity and food choices: an overview" Appetite 47(2) 196-204

Jabs J, Devine C M, Bisogni C A, Farrell T J, Jastran M, Wethington E, 2007, "Trying to find the quickest way: employed mothers' constructions of time for food" Journal of Nutrition Education and Behavior $3918-25$

Jacobs J A, Gerson K, 2001, "Overworked individuals or overworked families? Explaining trends in work, leisure and family time" Work and Occupations 28 40-63

Jarvis H, Pratt A C, Cheng-Cheong W, 2001 The Secret Lives of Cities: The Social Reproduction of Everyday Life (Prentice-Hall, Harlow, Essex)

Kawachi I, Kennedy B P, Wilkinson R G (Eds), 1999 The Society and Population Health Reader. Volume I: Income Inequality and Health (Free Press, New York)

Kellerman A, 1989 Time, Space and Society: Geographical Perspectives (Kluwer Academic, Dordrecht)

Kwan M, 1999, "Gender and individual access to urban opportunities: a study using time-space measures" The Professional Geographer 51211 - 227 
Kwan M, Weber J, 2003, "Individual accessibility revisited: implications for geographical analysis in the twenty-first century" Geographical Analysis 35341 - 353

Lakoff G, Johnson M, 1999 Philosophy in the Flesh: The Embodied Mind and Its Challenge to Western Thought (Basic Books, New York)

Lappalainen R, Saba A, Holm L, Mykkanen H, Gibney M J, 1997, "Difficulties in trying to eat healthier: descriptive analysis of perceived barriers for healthy eating" European Journal of Clinical Nutrition 51 S36-S40

Lundberg U, 1993, "On the psychobiology of stress and health", in Time Pressure and Stress in Human Judgment and Decision Making Eds O Svenson, A J Maule (Plenum Press, New York) pp $41-53$

Lundberg U, 2005, "Stress hormones in health and illness: the roles of work and gender" Psychoneuroendocrinology $301017-1021$

Lynch J, Kaplan G, 2000, "Socioeconomic position", in Social Epidemiology Eds L F Berkman, I Kawachi (Oxford University Press, Oxford) pp 13-35

Macinko J A, Starfield B, 2002, "Annotated bibliography on equity in health, 1980-2001" International Journal for Equity in Health 11 -20; http://www.equityhealthj.com/content/pdf/ 1475-9276-1-1.pdf

Massey D, 2005 For Space, (Sage, London)

May J, Thrift N, 2001, "Introduction", in Timespace: Geographies of Temporality Eds J May, N Thrift (Routledge, London) pp 1-46

Merz J, Rathjen T, 2009, “Time and income poverty — an interdependent multidimensional poverty approach with German time use diary data", DP 79, Forschungsinstitut Freie Berufe, Universität Lüneburg

Moser C, 1998, "The asset vulnerability framework: reassessing urban poverty reduction strategies World Development, 26(1) 1 - 19

Osland L, Thorsen I, 2008, "Effects on housing prices of urban attraction and labor-market accessibility" Environment and Planning A 402490 - 2509

Pocock B, 2003 The Work/Life Collision (Federation Press, Sydney)

Randolf B, Holloway D, 2005, "Social disadvantage, tenure and location: an analysis of Sydney and Melbourne" Urban Policy and Research 23173 - 201

Reidpath D, Burns C, Garrard J, Mahoney M, Townsend M, 2002, "An ecological study of the relationship between social and environmental determinants of obesity" Health and Place $\mathbf{8}$ $141-145$

Reisch L A, 2001, "Time and wealth: the role of time and temporalities for sustainable patterns of consumption" Time and Society 10(2/3) 367-385

Roberts C K, Barnard J R, 2005, "Effects of exercise and diet on chronic disease" Journal of Applied Physiology 93 3- 30

Robinson J, Godbey G, 2005, "Busyness as usual” Social Research 72 407-426

Roelen C A M, Schreuder K J, Koopmans P C, Groothoff J W, 2008, "Perceived job demands relate to self-reported health complaints" Occupational Medicine 5858 -63

Rose D, 2007, "Food stamps, the Thrifty Food Plan, and meal preparation: the importance of the time dimension for US nutrition policy" Journal of Nutrition and Education Behaviour 23 $226-232$

Ross C E, Mirowsky J, 1995, "Does employment affect health? Journal of Health and Social Behaviour 36(4) $230-243$

Roxburgh S, 2004, “'There just aren't enough hours in the day': the mental health consequences of time pressure" Journal of Health and Social Behaviour 45(6) $115-131$

Roxburgh S, 2006, "'I wish we had more time to spend together ...: the distribution and predictors of perceived family time pressures among married men and women in the paid labor force" Journal of Family Issues $27529-552$

Saelens B E, Salis J F, Black J B, Chen D, 2003, "Neighborhood-based differences in physical activity: an environment evaluation scale" American Journal of Public Health 931552 - 1558

Schwanen T, 2008, "Struggling with time: investigating coupling constraints" Transport Reviews $28337-356$

Sherwood N E, Jeffery R W, 2000, "The behavioral determinants of exercise: implications for physical activity interventions" Annual Review of Nutrition 2021 - 44

Shove E, 2009, "Everyday practice and the production and consumption of time", in Time, Consumption and Everyday Life Eds E Shove, F Trentmann, R Wilk (Berg, Oxford) pp 17-34

Southerton D, 2003, “'Squeezing time': allocating practices, coordinating networks and scheduling society" Time and Society 12(1) 5-25 
Spillerman S, 2000, "Wealth and stratification processes" Annual Review of Sociology 26 497-524

Strazdins L, Bammer G, 2004, "Women, work and musculoskeletal health" Social Science and Medicine 58997 - 1005

Strazdins L, Broom D H, Banwell C S, McDonald T, Skeat H, 2011, "Time limits? Reflecting and responding to time barriers for healthy, sustainable living in Australia" Health Promotion International 26(1) $46-54$

Strodl E, Kenardy J, 2008, "The 5-item mental health index predicts the initial diagnosis of nonfatal stroke in older women" Journal of Women's Health 17 979-986

Strodl E, Kenardy J, Aroney C, 2003, "Perceived stress as a predictor of the self-reported new diagnosis of symptomatic CHD in older women" International Journal of Behavioral Medicine 10(3) $205-220$

Takahashi L M, Weibe D, Rodriguez R, 2001, "Navigating the time-space context of HIV and AIDS: daily routines and access to care Social Science and Medicine 53 845-863

Taylor F W, 1911 The Principles of Scientific Management (Harper and Brothers, New York)

Tranter P J, 2010, "Speed kills: the complex links between transport, lack of time and urban health" Journal of Urban Health 87(2) 155 - 166

Vuckovic N, 1999, "Fast relief: buying time with medications" Medical Anthropology Quarterly 13(1) $51-68$

Wacjman J, 2008, "Life in the fast lane? Towards a sociology of technology and time" The British Journal of Sociology $5959-77$

Western M, Baxter J, Chester J, 2007, “How are families managing?”, in Australian Social Attitudes 2: Citizenship, Work and Aspirations Eds D Denemark, G Meagher, S Wilson, M Western, T Phillips (UNSW Press, Sydney) pp 291 - 261

WHO, 2005 The Bangkok Charter for Health Promotion in a Globalised World (World Health Organization, Geneva)

Young R, 1999, "Prioritising family health needs: a time - space analysis of women's health-related behaviours" Social Science and Medicine $48797-813$

Zuzanek J, 1998, "Time use, time pressure, personal stress, mental health, and life satisfaction from a life cycle perspective" Journal of Occupational Science 5(1) 26-39

Zuzanek J, 2004, "Work, leisure, time pressure and stress", in Work and Leisure Eds J T Haworth, A J Veal (Routledge, New York) pp 123-144 
Conditions of use. This article may be downloaded from the E\&P website for personal research by members of subscribing organisations. This PDF may not be placed on any website (or other online distribution system) without permission of the publisher. 